\title{
Çocukluk çağında paratiroid hormon bağımlı hiperkalsemi: üç olgu nedeni ile
}

\section{Parathyroid hormone dependent hypercalcemia in childhood: due to three cases}

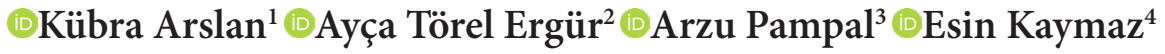 \\ ${ }^{1}$ Ufuk Üniversitesi Tip Fakültesi, Çocuk Sağlığı ve Hastalıkları Anabilim Dalı, Ankara, Türkiye \\ ${ }^{2}$ Ufuk Üniversitesi Tip Fakültesi, Pediatrik Endokrinoloji Bilim Dalı, Ankara, Türkiye \\ ${ }^{3}$ Ufuk Üniversitesi Tip Fakültesi, Çocuk Cerrahisi Anabilim Dalı, Ankara, Türkiye \\ ${ }^{4}$ Ufuk Üniversitesi Tip Fakültesi, Tibbi Patoloji Anabilim Dalı, Ankara, Türkiye
}

Cite this article as / Bu makaleye atıf için: Arslan K, Törel Ergür A, Pampal A, Kaymaz E. Çocukluk çağında paratiroid hormon bağımlı hiperkalsemi; üç olgu nedeni ile. J Med Palliat Care 2021; 2(1): 28-34.

\section{ÖZ}

Ciddi çocukluk çağı hiperkalsemisi, düzeltilmediği takdirde koma ve ölümle sonuçlanabilen önemli bir bulgudur. Öte yandan etiyoloji ve tedavi yaklaşımları yaşa göre değişkenlik göstermektedir. Bu nedenle tanının doğru ve ivedilikle konulması önem arz eder. Bu yazıda, hiperkalsemi saptanan üç farklı olguda tanı ve tedavi yaklaşımlarının literatür eşliğinde sunulması uygun görülmüştür.

Anahtar Kelimeler: Çocukluk çağı hiperkalsemisi, etiyoloji, tedavi

\begin{abstract}
Severe childhood hypercalcemia appears as a serious finding that can result in coma and death if not corrected. On the other hand, etiology and treatment approaches vary according to age. Therfore it is important to make the diagnosis correctly and promptly. In this article, it was deemed appropriate to present the diagnosis and treatment approaches in three cases with different diagnosis due to hypercalcemia in the light of the literature.
\end{abstract}

Keywords: Childhood hypercalcemia, etiology, treatment

\section{Gíriș}

Vücuttaki kalsiyumun büyük çoğunluğu kemiklerde kalsiyum fosfat tuzları şeklinde, az bir kısmı da hücreler ve ekstrasellüler sıvıda farklı formlarda bulunur. Hiperkalsemi, serumda bulunan ve kalsiyumun aktif formu olan iyonize kalsiyum değerinin yaşa ve cinsiyete göre düzenlenmiş ortalama değerlerinin iki standart deviyasyonunun üzerinde olması olarak tanımlanır ve hayatı tehdit eden bir durumdur. Bu sebeple tanısinın doğru konulup tedavisinin ivedilikle yapılması önem arz eder. Genel olarak kullanılan ortalama değer aralığı 8,8 mg/dL-10,8 mg/dL (1) olsa da serum kalsiyum düzeyinin yaşa göre değişimi gelişim basamaklarının normal fizyolojisini yansıtır (2). Pediatrik yaş grubunda normal serum kalsiyum konsantrasyonları, yeni doğan ve süt çocuğu döneminde en yüksek olup çocukluk ve ergenlik evrelerinde düşüşe geçer ve 17 yaş civarında dengelenerek erişkin değerlerine gelir (1). Çocuklarda hiperkalsemi paratiroid hormon (PTH) bağımlı ve PTH bağımsız olarak sinıflandırılabilir. Hiperkalsemi ile sonuçlanan bu hastalıklar, konjenital veya sonradan kazanılmış mekanizmalara bağlı olabilir. PTH bağımsız hiperkalsemilerde serum kalsiyum düzeyinin başka bir etkene bağlı olarak yükselmiş olması, serum PTH düzeyini baskılar. Çocuklarda görülen bazı genetik anormallikler, metabolik bozukluklar, endokrinopatiler, hipervitaminozlar ve granülomatöz hastalıklar, PTH bağımsız hiperkalseminin sebeplerindendir ve çocukluk çağı hiperkalsemi etiyolojisinde PTH bağımlı 
hiperkalsemiden daha sık görülürler. PTH bağımlı hiperkalsemi ise en sık paratiroid adenomuna bağlı olarak görülür $(2,3)$. Bu adenom primer olarak paratiroid bezinde bulunabilir, ektopik yerleşimli olabilir veya kronik böbrek yetmezliği gibi bir sebebe bağlı olarak tersiyer kökenli olabilir. Yeni doğanlarda PTH bağımlı hiperkalsemi, maternal hipokalsemi sebebiyle gelişebilir (2).

\section{Serum Kalsiyum Dengesi Nasıl Sağlanır?}

Kalsiyum vücutta pek çok hayati fonksiyonda kullanılır. Kas kasılması, sinir iletimi, kemik metabolizması ve koagülasyon, kalsiyumun başlıca görev yerlerindendir. Kalsiyum, hedef organlarda gerçekleştireceği etkisini CaSR adı verilen reseptörler veya reseptör kullanmaksızın iyon kanalları aracılığıyla gerçekleştirir. Bu reseptörler primer olarak paratiroid bezlerinde ve renal tübüllerde bulunur (4,5). Vücuttaki kalsiyum dengesi başlica PTH ve D vitamini ile sağlanır. Bunlar kalsiyumun serumdaki değerlerine göre devreye giren geri bildirim mekanizması üzerinden işler. Serum kalsiyum seviyesi eşik değeri geçecek olursa paratiroid bezindeki şef hücrelerde bulunan CaSR'ler aktive olur ve PTH salınımı inhibe edilir. Ayrıca yine bu reseptörler aracılığıyla renal tübüllerde kalsiyum emilimi ve $\mathrm{D}$ vitamininin böbrekte aktif forma dönüşümü azaltılır (Şekil) (6).
Primer Hiperparatiroidizm (PHPT): PHPT sıklıkla izole, sendromik veya genetik geçişi olmayan bir endokrinopatidir. Pediatrik yaş grubunda nadir görülür. Pediatrik PHPT’nin en sık sebebi \%80'lik oranla sporodik adenomdur. Bunun dişında familyal hipokalsiürik hiperkalsemi (FHH), MEN sendromları, familyal izole hiperparatiroidizm, neonatal ağır primer hiperparatiroidizmden de kaynaklanabilir $(2,8)$.

Tersiyer Hiperparatiroidizm (THPT): THPT, en sik kronik böbrek yetmezliği, bazen de hipofosfatemik rikets tedavisi (kalsimimetik tedavi) sürecine bağlı olarak görülür $(2,9)$. Serumda bir nedene bağlı olarak düşük olarak bulunan kalsiyum seviyelerini organizmanın fizyolojik sınırlarında tutmak üzere PTH miktarının artırılması gerekliliği zamanla paratiroid bezinde hipertrofi ile sonuçlanır (9).

Serum kalsiyum seviyesi yüksek olan olgularda tanıya yönelik algoritmadan Tablo 1 'de bahsedilmiştir (3). Bu makalede, bahsedilen algoritmalar kullanılarak tanıya gidilen ve çocukluk çağında paratiroid hormon bağımlı hiperkalsemi başlı̆̆ altında farklı tanılar alan üç olgudan bahsedilmiştir.

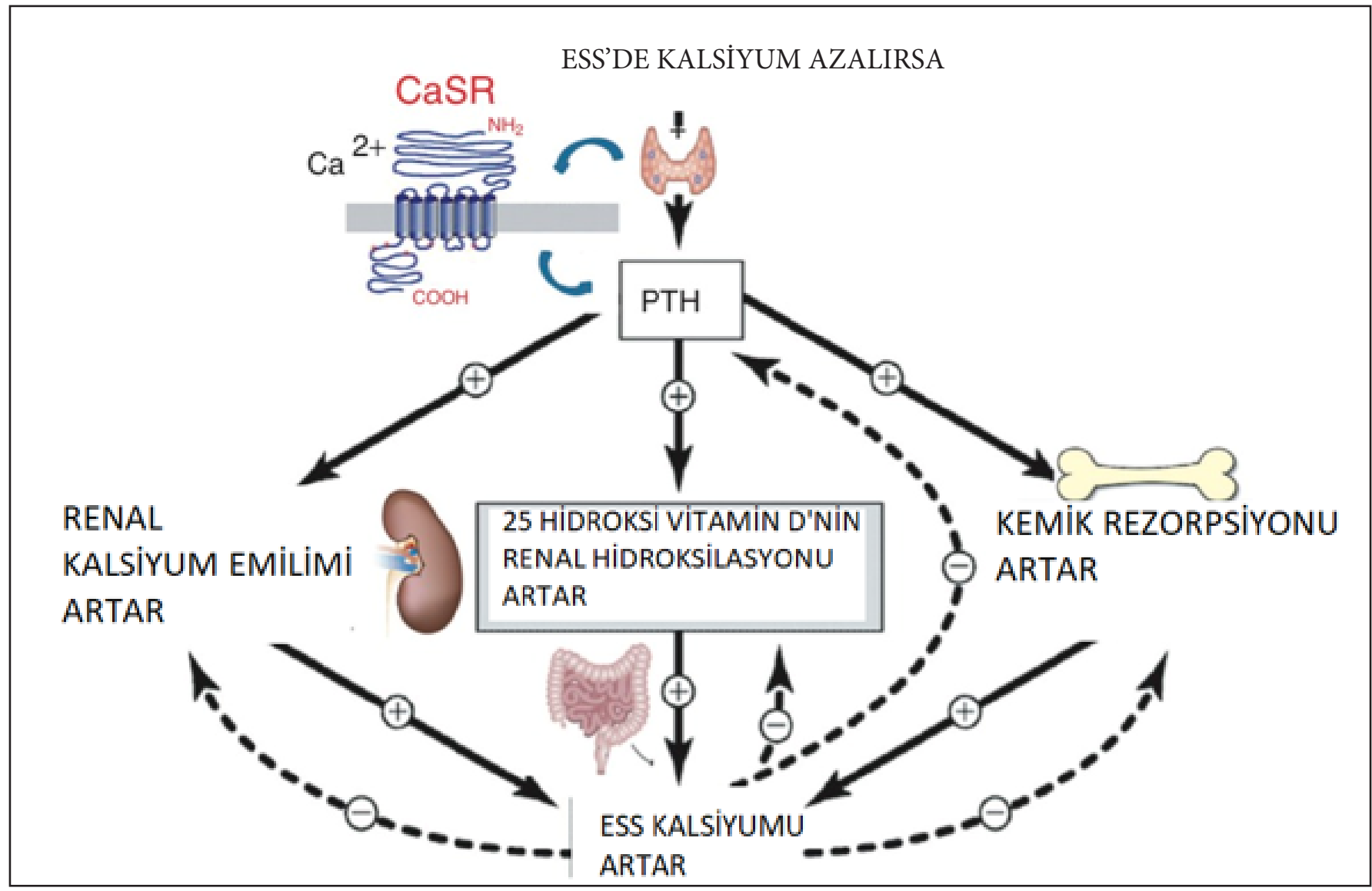

SSekil. CaSR geni ekstraselüler sıvıdaki (ESS) Ca seviyesini ayarlamada etkindir. ESS'deki Ca miktarının azalması CaSR geninin aktivitesini azaltır. Inaktive olan gen, paratiroid bezinden PTH salınımını artırır. Bu durum da hem Ca emilimini artırarak hem de D vitamininin aktif forma dönüşümünü sağlayarak serum kalsiyum düzeyini yükseltir. Ca seviyesinin normale dönmesi CaSR genini aktifleștirir ve PTH salınımı inaktive olur (7).

PTH: Prathormon, ESS: Ekstraselüler siv1 
Tablo 1. Çocukluk çağında hiperkalsemiye yaklaşım

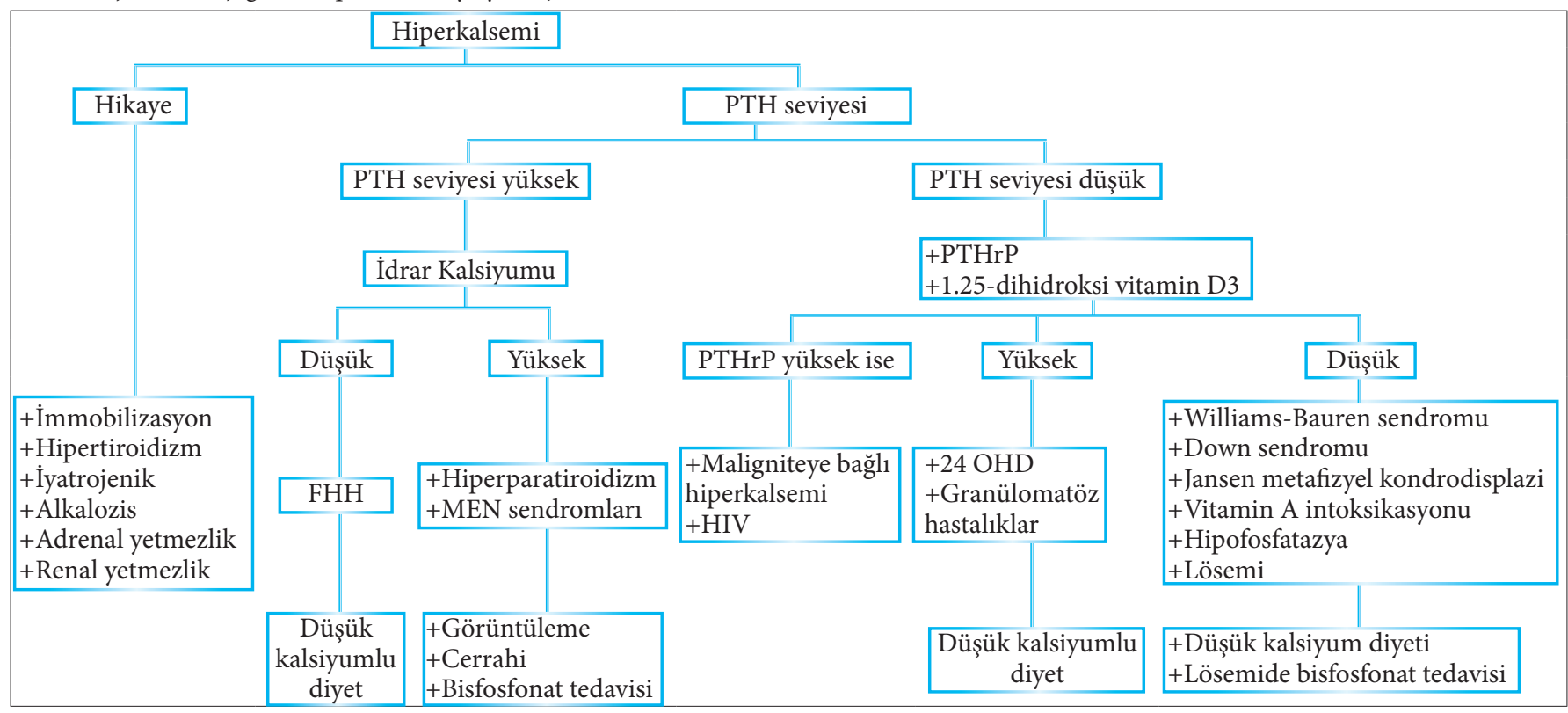

FHH: Familyal hipokalsiürik hiperkalsemi, PTH: Paratiroid hormon

\section{OLGU 1}

On üç yaş 8 aylık kız hasta, polikliniğimize ağız çevresinde uyuşma şikayeti ile başvurdu. Somatik gelişimi yaşına uygun olan hastanın dismorfik bulguları yoktu ve fizik muayenesi doğaldı. Özgeçmişinde bir özellik yoktu. Soy geçmişinde ise babada sol el üç orta parmak agenezisi (yarık el deformitesi; cleft hand) mevcuttu. Yapilan kan tetkiklerinde serum kalsiyum değeri $12 \mathrm{mg} / \mathrm{dL}$ ve PTH değeri $273 \mathrm{ng} / \mathrm{L}$ olarak ölçüldü. Bu parametrelere eşlik eden fosfor ve ALP (alkalen fosfataz) yüksekliği yoktu. Hastada hiperkalsemi sebepleri araştırıldığında tiroid USG'sinde paratiroid lojuna uygun ekojeniteye rastlanıldı. Hastanın idrar kalsiyum/kreatinin $(\mathrm{Ca} / \mathrm{Kre})$ oranına bakıldığında 0,13 olarak normal değerde olduğu tespit edildi. Multisistemik tarama yapilarak sendromik genetik tanılar (Williams sendromu?) dışlandı. Hastanın paratiroid sintigrafisi yapıldığında sol alt paratiroid bezinde adenom tespit edildi. Eşlik edebilecek tiroidparatiroid malignitelerinin ekarte edilmesi amacıyla tümör markırları değerlendirildi. D vitamini intoksikasyonunu dışlamak amacıyla 25 hidroksi vitamin D ve granülamatöz hastalıkların dışlanması amacıyla 1,25-dihidroksivitamin düzeyleri değerlendirildi. CasR gen ve MEN mutasyonu için genetik analizi yapıldı. MEN genetik incelemesi normal olarak gelen, de novo mutasyon da saptanmayan hasta, izole paratiroid adenomu olarak Çocuk Cerrahisi bölümüne refere edildi. Opere edile olguda hem makroskopik hem histopatolojik değerlendirme paratiroid adenomunu $(1,2 \times 0,5 \times 0,6 \mathrm{~cm})$ ile uyumlu idi (Resim 1, 2, 3). Postoperatif birinci günde çalışılan serum PTH değeri 20,3 ng/L gelerek normal sınırlara indi. Hastanın anne ve babasından çalıșllan kan tetkiklerinde her ikisinin de serum kalsiyum, fosfor, ALP normal olarak değerlendirildi. Hastanın babasında da PTH yüksekliği tespit edilmesi üzerine aile genetik danışmanlık alması ve babanın da olası adenom açısından değerlendirilmesi amacıyla yönlendirildi.

\section{OLGU 2}

Altı yaş 8 aylık kız hasta, çocuk endokrin polikliniğinde hipotiroidi ile takipli ve asemptomatik iken bakılan kontrol kan tetkiklerinde $\mathrm{PTH}$ yüksekliği saptanması üzerine değerlendirildi. Hastanın hikayesi ve fizik muayenesinde bir özellik yoktu. Büyüme ve gelişmesi yaşı ile uyumluydu. Hastanın bir sene öncesinde bakılan ilk PTH değeri 92,7 ng/L olarak tespit edilmiş olup, eş zamanlı alınan kan kalsiyum, fosfor, magnezyum ve ALP düzeyleri normaldi. Hasta subklinik rikets ve sekonder hiperparatiroidizm ön tanıları ile takibe alındı. Hastanın 3 ay sonra bakılan kontrol kan tetkiklerinde PTH düzeyi 102,9 ng/L olarak saptandı. Yine eş zamanlı alınan kan kalsiyum, fosfor ve ALP düzeyleri normal olarak değerlendirildi. İdrarda bakılan kalsiyum/kreatinin oranı 0,01 ile düşük olarak değerlendirildi. İdrarda kalsiyum atılımının düşük ve serum PTH değerinin yüksek olmasına rağmen, idrarda kalsiyum atılımının düşük olması otozomal dominant geçişli familyal hipokalsiürik hiperkalsemi (FHH) tanısını düşündürdü. Hastada ayırıcı tanıya yönelik olarak CaSR gen mutasyonu tayini ve ebeveynlerinden idrarda $\mathrm{Ca} / \mathrm{Kre}$ oranı istendi. Hastanın anne ve babasından çalışılan kan tetkiklerinde anne ve babanın idrarda $\mathrm{Ca} / \mathrm{Kre}$ oranları ile serum kalsiyum, fosfor, magnezyum, ALP düzeyleri normaldi. Annenin serum PTH değeri 126 ng/L ile yüksek, babanın serum PTH değeri 57,6 ng/L ile normal olarak sonuçlandı. Anne, baba ve çocuktan CaSR gen mutasyonu istendi, ancak mutasyon tespit edilemedi. Bu yönüyle hastada henüz tespit edilememiş de novo mutasyon ekarte edilemediğinden genetik danışmanlık için yönlendirildi. 

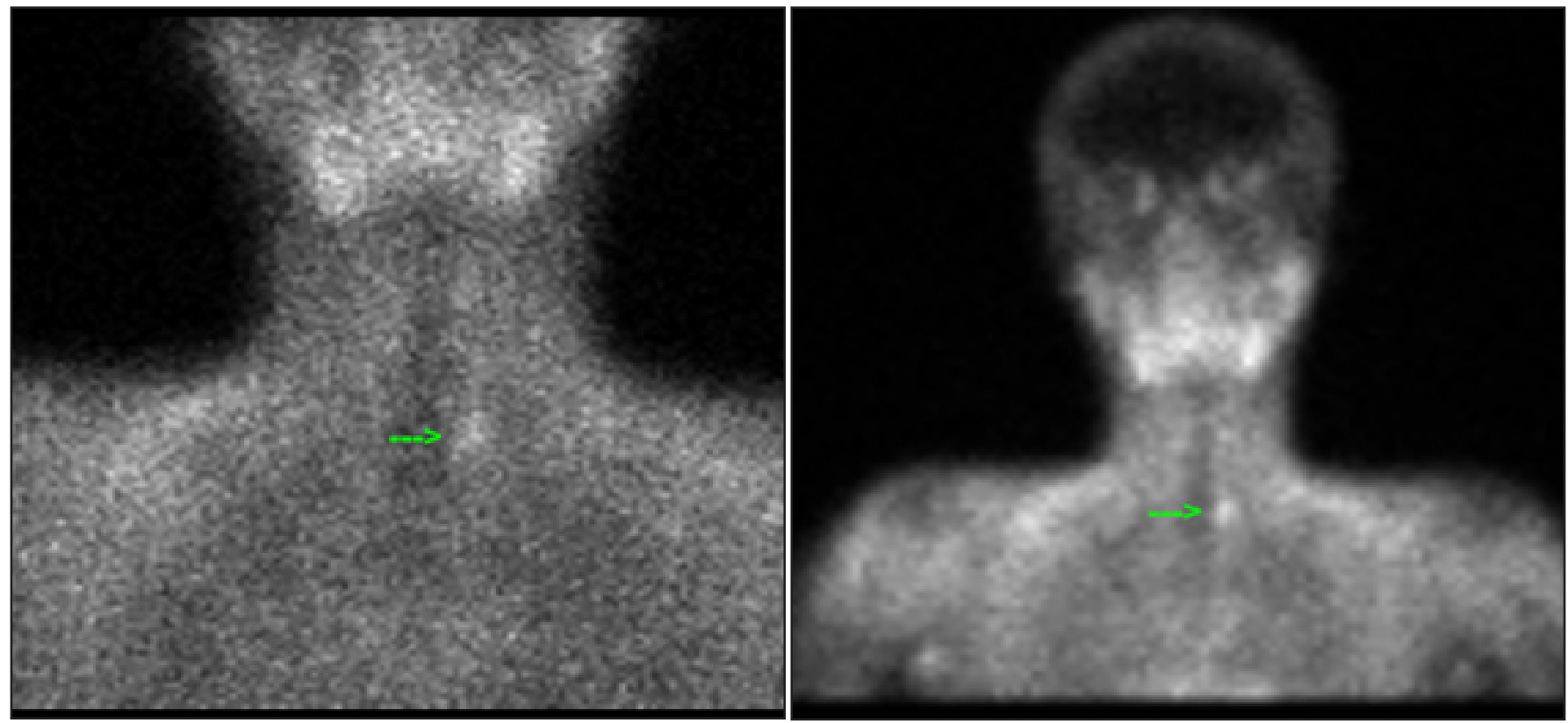

Resim 1. Olgu 1'de paratiroid sintigrafisinde gözlenen paratiroid adenomu

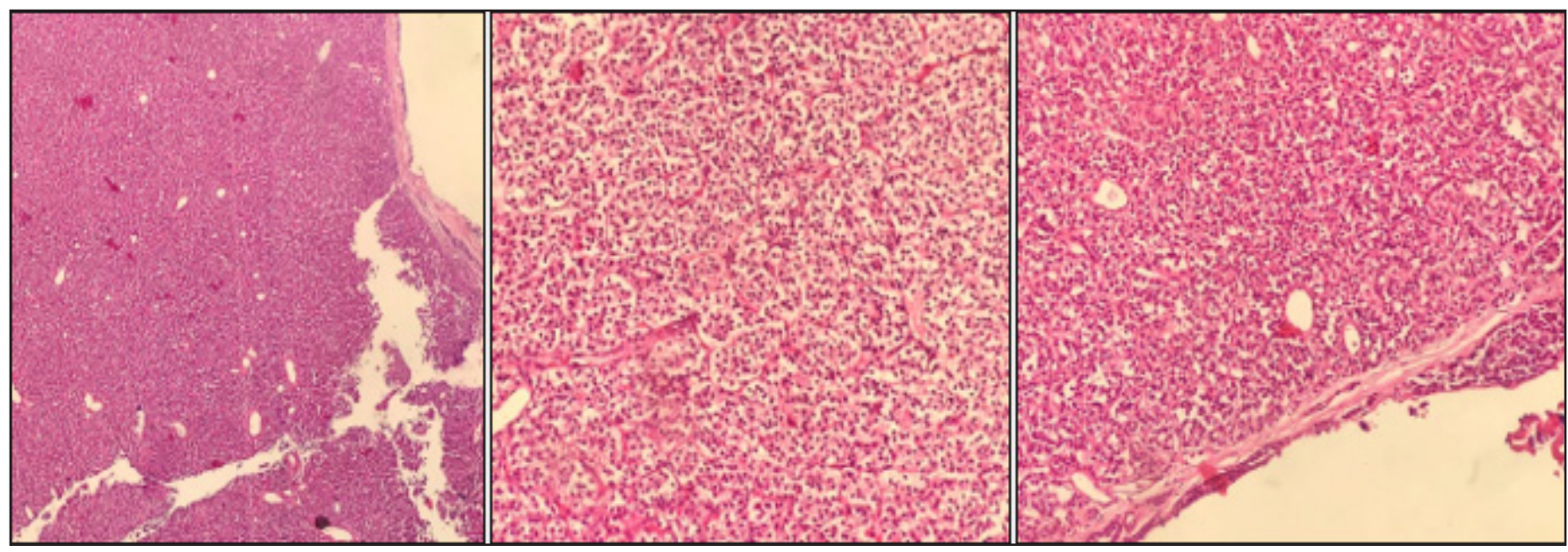

Resim 2. Olgu 1'in paratiroid adenomunun mikroskobik görünümü

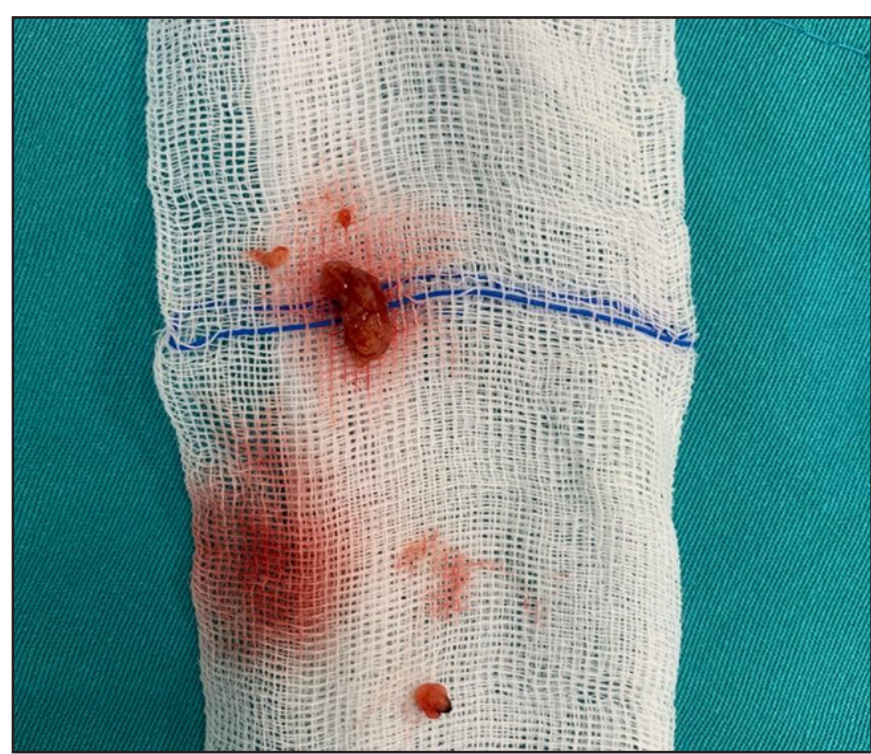

Resim 3. Olgu 1'in paratiroid adenomunun makroskobik görünümü $(1,2 \times 0,5 \times 0,6 \mathrm{~cm})$

\section{OLGU 3}

Üç aylık kız hasta, TSH düzeylerinin yüksek olması dolayısıyla Çocuk Endokrin polikliniğimize başvurdu. 38 haftalık gebelik sonrasında 3950 gram olarak doğan olgunun antropometrik değerlendirmesi ve fizik muayenesi normaldi. Hipertirotiropinemi ile izlenen olgunun 5 aylıkken yapılan kontrol muayenesinde serum kalsiyum düzeyi $11,34 \mathrm{mg} / \mathrm{dL}$ olarak ölçüldü. Hiperkalsemi kliniğine ait hiç bir semptomu olmayan olgunun serum kalsiyum, fosfor, ALP, vitamin D düzeyi, idrarda kalsiyum/kreatinin oranı, idrar tetkiki normaldi. Hiperkalsemiye rağmen idrarda kalsiyum atılımı normaldi. Hiperkalseminin etiyolojisini araştırmak amaciyla olgunun anne ve babasının biyokimyasal ve hormonal parametreleri değerlendirildi, normal olarak sonuçlandi. Hastada yapılan genetik incelemesinde CaSR geni ekzon 7'de homozigot mutasyon (p.Glu1011Gln/ c.3031G>C) tespit edildi (Tablo 2, 3, 4). 


\begin{tabular}{|c|c|c|c|}
\hline Parametre & Olgu 1 & Olgu 2 & Olgu 3 \\
\hline Yaş (yıl) & 13 yaş 8 ay & 6 yaş 8 ay & 5 ay \\
\hline Cinsiyet & $\mathrm{K} 1 \mathrm{z}$ & $\mathrm{K} 1 \mathrm{z}$ & Kız \\
\hline $\begin{array}{l}\text { Puberte } \\
\text { (Tanner) }\end{array}$ & P2 & P1 & P1 \\
\hline Ağırlık (kg) & $48,3(27 \mathrm{P})$ & $26,8(82 \mathrm{P})$ & 7,3 (69P) \\
\hline Boy $(\mathrm{cm})$ & 163,5 (74 P) & 128,5 (94 P) & $63(32 \mathrm{P})$ \\
\hline BMI & 18,07 & 16,05 & 18,39 \\
\hline BMIp & $15 \mathrm{P}$ & $64 \mathrm{P}$ & $85 \mathrm{P}$ \\
\hline Yakınma & $\begin{array}{l}\text { Çenede } \\
\text { uyuşma }\end{array}$ & $\begin{array}{l}\text { Aktif şikayet } \\
\text { yok }\end{array}$ & $\begin{array}{c}\text { Aktif şikayet } \\
\text { yok }\end{array}$ \\
\hline Kemik yaşı & $\begin{array}{c}\text { Takvim yaşı ile } \\
\text { uyumlu }\end{array}$ & $\begin{array}{c}\text { Takvim yaşı ile } \\
\text { uyumlu }\end{array}$ & $\begin{array}{c}\text { Takvim yaşı ile } \\
\text { uyumlu }\end{array}$ \\
\hline
\end{tabular}

\begin{tabular}{|c|c|c|c|}
\hline & Olgu 1 & Olgu 2 & Olgu 3 \\
\hline $\begin{array}{l}\text { Serum Ca (mg/ } \\
\text { dL) }\end{array}$ & 12 & 10 & 11,34 \\
\hline $\begin{array}{l}\text { Serum PTH } \\
(\mathrm{ng} / \mathrm{L})^{* \star}\end{array}$ & 273 & 102,9 & 13 \\
\hline $\begin{array}{l}\text { ALP, } \\
\text { Magnezyum ve } \\
\text { fosfor (P) }\end{array}$ & NORMAL & NORMAL & NORMAL \\
\hline $\begin{array}{l}\text { Tiroid fonksiyon } \\
\text { testleri }\end{array}$ & NORMAL & NORMAL & NORMAL \\
\hline $\begin{array}{l}\text { hTG (human } \\
\text { tiroglobulin) }\end{array}$ & NORMAL & NORMAL & NORMAL \\
\hline $\begin{array}{l}\text { Spot idrar Ca/ } \\
\text { Kre }\end{array}$ & 0,13 & 0,01 & 0,03 \\
\hline $\begin{array}{l}\text { Paratiroid } \\
\text { sintigrafisi }\end{array}$ & $\begin{array}{l}\text { Paratiroid } \\
\text { adenomu }\end{array}$ & - & - \\
\hline Genetik analizi & $\begin{array}{l}\text { CaSR: Negatif } \\
\text { MEN: Negatif }\end{array}$ & CaSR: Negatif & $\begin{array}{c}\text { CaSR: } \\
\text { p.Glu1011Gln/ } \\
\text { c. } 3031 \mathrm{G}>\mathrm{C})\end{array}$ \\
\hline \multicolumn{4}{|c|}{$\begin{array}{l}\text { **PTH: } 10-65 \mathrm{ng} / \mathrm{dL} \\
* * * \text { Mg: } 1.6-2.3 \mathrm{mg} / \mathrm{dL} \\
+ \text { +Ca/Kre: } 0.02-0.2 \\
++\mathrm{P}:<18 \text { yaș: } 3.1-5.4 \mathrm{mg} / \mathrm{dL} ;>18 \text { yaş: } 2.5-4.5 \mathrm{mg} / \mathrm{dL} \\
+++ \text { ALP: }<20 \text { yaș: } 25-100 \mathrm{IU} / \mathrm{L} ;>20 \text { yas: } 25-100 \mathrm{IU} / \mathrm{L}\end{array}$} \\
\hline
\end{tabular}

\begin{tabular}{|c|c|c|c|c|c|c|}
\hline & \multicolumn{2}{|c|}{ Olgu 1} & \multicolumn{2}{|c|}{ Olgu 2} & \multicolumn{2}{|c|}{ Olgu 3} \\
\hline & Anne & Baba & Anne & Baba & Anne & Baba \\
\hline $\mathrm{Ca}(\mathrm{mg} / \mathrm{dL})$ & 10 & 9,7 & 10,37 & 10,7 & 9,8 & 10,1 \\
\hline $\mathrm{P}(\mathrm{mg} / \mathrm{dL})++$ & 2,9 & 3,4 & 2,52 & 2,8 & 2,7 & 2,9 \\
\hline $\operatorname{ALP}(\mathrm{U} / \mathrm{L})+++$ & 74 & 130 & 83 & 90 & 87 & 98 \\
\hline PTH (ng/L) & 29 & 68,4 & 126 & 57,6 & 25 & 39 \\
\hline $\operatorname{Mg}(\mathrm{mg} / \mathrm{dL})^{\star * \star}$ & 1,8 & 1,9 & 2,07 & 2,16 & 1,97 & 2 \\
\hline $\mathrm{Ca} / \mathrm{Kre}$ & 0,09 & 0,1 & 0,04 & 0,03 & 0,08 & 0,09 \\
\hline $\begin{array}{l}{ }^{*} \mathrm{Ca}: 8,8-10,8 \mathrm{mg} / \mathrm{dL} \text {, } \\
+ \text { +Ca/Kre: } 0,02-0,2 \\
++\mathrm{P}:<18 \text { yaș: } 3,1-5,4 \\
+++ \text { ALP: }<20 \text { yaş: } 25\end{array}$ & $\begin{array}{l}\text { PTH: } 10 \\
\text { gg/dL; >1 }\end{array}$ & $5 \mathrm{ng} / \mathrm{d}$ & $\begin{array}{l}{ }^{*} \mathrm{Mg}: 1,6 \\
\mathrm{mg} / \mathrm{dL}\end{array}$ & & & \\
\hline
\end{tabular}

\section{TARTIŞMA}

Hiperkalsemi çocukluk çağında nadir görülen ve önem arz eden bir bulgudur. Tanı ve tedavi aşamasında hızlı ve doğru karar vermek, hastada gelişebilecek uç organ hasarını en aza indirmek ve hayati tehlikesini önlemek amaciyla önemlidir (10). Hiperkalsemi saptanan çocuklarda eşlik eden PTH yüksekliği varlığında PHPT’nin bir klinik varyantı olarak kabul edilen FHH gibi genetik sendromların (2) ve paratiroid adenomu ile takip edilen hastaların ayırıcı tanısı gereksiz cerrahi girişimleri önlemesi açısından önemlidir; çünkü çocukluk çağında hiperkalsemik vakaların \%1'inden azını oluşturduğu bildirilmiştir (10,11). Ayrıca adenom, paratiroid bezi hiperplazisi ve nadiren karsinoma bağlı olarak gelişen PHPT'de başvuran çocuk hastaların \%85’i semptomatiktir (12). Bu vakalar semptomatik olmasina rağmen çok nadir görülmesi sebebiyle klinik takipte atlanabilmektedir. Nitekim olgu 1'in adölesan yaşa kadar takip edildiği merkezlerde tanı alamaması dikkat çekicidir ve bu yönüyle hiperkalsemi etiyolojisinde klinisyenlere yol gösterici olması açısından önem arz etmektedir.

Primer hiperparatiroidizm'de nadiren de olsa PTH düzeyleri normal olabileceği ve vaka asemptomatik ise bu durumda FHH'den klinik ve biyokimyasal olarak ayırt edilemeyebileceği göz önünde bulundurulmalıdır (13). Bunun yanında literatürde hiperkalsemik semptomları olduğu halde serum PTH düzeyleri düşük tespit edilen, tanı sirasinda yapılan ultrason ve teknesyum-99msestamibi sintigrafisi ile paratiroid adenomu tanisı alan bir vaka bildirilmiştir. Bu vakada ezber bozan bu biyokimyasal ikilem, klasik serum PTH ölçüm yöntemleri ile ölçülemeyen anormal PTH molekülleri ile açılanmıştır $(10,11)$.

Ayırıcı tanıda izlenecek yolda FHH tanısında, otozomal dominant olarak kalitılması sebebiyle hem aile bireylerinin taranması hem de FHH'nin klinik olarak tanımlanmış mutasyonlarının analiz edilmesi faydalı olabilir (14). İkinci olgumuzda, anne ve babadan spot idrarda $\mathrm{Ca} / \mathrm{Kre}$ oranı, tanı için yol gösterici olmadığ 1 için genetik araştırma gerekmiştir. En sık görülen mutasyonları ile esas olarak 3 ayrı tiplemesi yapılan FHH için CaSR'de tanımlanan 200'den fazla mutasyon tespit edilmiştir; ancak vakaya özel tespit edilen CaSR mutasyonlarında genotip-fenotip arasında güçlü korelasyon tespit edilememiştir (15). CaSR mutasyonu tespit edilen hastaların genelinin fenotipi normaldir ve çoğu asemptomatiktir. Olguların \%98'inde $\mathrm{Ca} / \mathrm{Kre}$ oranı $<0,01$ 'in altındadır. Normalde literatürde tanımlanan ekzon 7 gen mutasyonlarının $\mathrm{FHH}$ için heterozigot mutasyonu olduğu bildirilmiş (16) ise de ilginç olarak üçüncü vakamızın ekzon 7'deki mutasyonu homozigot mutasyon (p.Glu1011Gln/c.3031G>C) olarak tespit edilmiştir. Ayrıca olgumuzun tespit edilen genotipi klinik olarak FHH ile uyumlu olup bu yönüyle literatürdeki bilgiye katkı sağlamıştır. FHH genetiğinde suçlanan mutasyonların \%20'sinin henüz tanımlanmamış olduğu düşünülmektedir (17); üçüncü vakamız da henüz tanımlanmamış bu grubun içindedir. Lopez ve ark. adaşlarının yayınladığı bir olgu sunumunda CaSR geninde (ekzon 7) nükleotid değişimli yeni bir mutasyon (c.2089G > A) tanımlanmıștır (18). Bu mutasyon hastanın annesi ve erkek kardeşinde de tespit edilmiştir. Yeni tespit 
edilen mutasyonların yanında en sık görülen tipi olan FHH1' de 3. kromozomda CaSR geni üzerinde heterozigot inaktive edici mutasyon vardır. $\mathrm{Bu}$ sendrom MarxAuerbach sendromu veya Ailevi benign hiperkalsemi olarak da anılır. Bu tipin prognozu oldukça iyi olup, beklenen yaşam süresinde belirgin bir düşüş olmadığ1 bildirilmiştir. Bu durum, çoğunluğu asemptomatik olan vakaların klinik olarak tespit edilememesinden kaynaklı olabilir (19). CaSR mutasyonu tespit edilen vakaların \%98'inde Ca/Kre oranı <0,02'dir (16). İkinci olgumuzun $\mathrm{Ca} / \mathrm{Kre}$ oranı da bu bilgiyi destekler nitelikteydi. FHH2'de GNA11 geninin G-protein alt birimi a11'i kodladığı 19p13.3 lokasyonunu içeren bölgede mutasyon vardır. Bu tip magnezyum ilişkili tip olarak geçip bu vakalarda FHH kliniğine ek olarak hipermagnezemi görülür (17). Vakalarımızda hipermagnezemi olmaması, tanıda FHH2'den uzaklaştırmıştır. FHH3'de AP2S1 geninin kodladığı adaptör ilişkili protein kompleks- 2 ve sigma-1 alt birimlerinde mutasyon vardir $(15,20)$. Tip 2 ve 3'de ayrıca öğrenme güçlüğü ve nöropsikiyatrik bulguların da olabileceğine dair yayınlar vardır (21). Vakalarımızda bu özelliklerin olmaması ile bu FHH tip 2 ve 3, olası tanılarını desteklememektedir. Literatürde bildirilen FHH'li olgularda dikkat edilmesi gereken diğer bir husus da hiperkalsemiye bağlı gelişebilecek tekrarlayan pankreatit ataklarıdır. Bu sebeple klinik yakınma açısından karın ağrısı, laboratuvar değerlendirmesi açısından amilaz takibi, semptomatik vakalarda önem arz eder (19). Literatürde 6 yaşında büyüme geriliği ve sık tekrarlayan otit ile takip edilirken timpanoplasti yapılan, operasyon sonrasında timpanik membranda iyileşme dokusunda kalsiyum depozitleri biriken bir olguda etiyoloji araştırılırken CaSR inaktive edici mutasyonu tespit edilmiştir (22). Olgudaki bu birliktelik, bu yönüyle literatürde ilginç bir vaka olarak yerini almıştır.

Hiperkalsemi tedavisi etiyolojiye ve serum kalsiyum düzeyine yönelik olarak yapılmalıdır. Olgularımızın ilkinde saptanan paratiroid adenomu gibi durumların tedavisi için hastaların çocuk cerrahisi'ne yönlendirilmesi gerekir. Olgu 1, ivedilikle çocuk cerrahisi bölümüne refere edilmiş ve tanısı ile opere edilmiştir. Diğer olgularımız gibi $\mathrm{FHH}$ tespit edilen vakalarda, hasta asemptomatik ise tedavi endikasyonu yoktur (18). Bizim hastamız da asemptomatik olduğu için tedavi başlanmadı. Hasta semptomatikse, serum $\mathrm{Ca}>11,2 \mathrm{mg} / \mathrm{dL}$ ise veya $\mathrm{Ca}$ üst limitinden $1 \mathrm{mg} / \mathrm{dL}$ fazla ise kullanılan sinakalset tedavisinin gündeme gelebileceği bildirilmiştir. İlaca devam etme kararını vermede, semptomların düzelmesi ve serum kalsiyum düzeylerinin ortalama 8-12 haftada normal değerlere dönmesi tedaviye yeterli yanıt olarak değerlendirilmiştir (23). Ancak 18 yaş altı olgularda FDA onayı olmayıp sinakalset kullanımının güvenliği ve etkinliğinin bilinmediği belirtilmiștir.

\section{ETIKK BEYANLAR}

Aydınlatılmış Onam: $\mathrm{Bu}$ çalışmaya katılan hastalardandan yazılı onam alınmıştır.

Hakem Değerlendirme Süreci: Harici çift kör hakem değerlendirmesi.

Çıkar Çatışması Durumu: Yazarlar bu çalışmada herhangi bir çıkara dayalı ilişki olmadığını beyan etmişlerdir.

Finansal Destek: Yazarlar bu çalışmada finansal destek almadıklarını beyan etmişlerdir.

Yazar Katkıları: Yazarların tümü; makalenin tasarımına, yürütülmesine, analizine katıldığını ve son sürümünü onayladıklarını beyan etmişlerdir.

\section{KAYNAKLAR}

1. Sadiq NM, Naganathan S, Badireddy M. Hypercalcemia. In: StatPearls [Internet]. Treasure Island (FL): StatPearls Publishing; 2020 Jan.

2. Stokes VJ, Nielsen MF, Hannan FM, et al. Hypercalcemic disorder in children. J Bone Miner Res 2017; 32: 2157-70.

3. Hochberg Z. Practical Algorithms in Pediaric Endocrinology. 3rd ed. Haifa: Karger: 2017. pp 68-9.

4. Riccardi D, Brown EM. Physiology and pathophysiology of the calcium-sensing receptor in the kidney. Am J Physiol Renal Physiol 2010; 298: F485-99.

5. Shah VN, Chagot B, Chazin WJ. Calcium-dependent regulation of ion channels. calcium bind proteins 2006; 1: 203-12

6. Egbuna OI, Brown EM. Hypercalcaemic and hypocalcaemic conditions due to calcium-sensing receptor mutations. Best Pract Res Clin Rheumatol 2008; 22: 129-48.

7. Diaz-Soto G, Rocher A, Garcia-Rodriguez C, et al. The calcium sensing receptor in health and disease. Int Rev Cell Mol Biol 2016; 327: 321-69.

8. Dutta A, Pal R, Jain N, et al. Pediatric parathyroid carcinoma: a case report and review of literature. J Endocr Soc 2019; 3: 2224-35.

9. Hirai T, Nakashima A, Takasugi N, et al. Association of nodular hyperplasia with resistance to cinacalcet therapy for secondary hyperparathyroidism in hemodialysis patients. Ther Apher Dial 2010; $14:$ 577-82.

10.Davies JH. Approach to the child with hypercalcemia. Endocr Dev. Basel, Karger, 2015, vol 28, pp 101-18

11. Benaderet AD, Burton AM, Clifton-Bligh R, et al. Primary hyperparathyroidism with low intact PTH levels in a 14-year-old girl. J Clin Endocrinol Metab 2011; 96: 2325-9.

12. Roizen J, Levine MA. Primary hyperparathyroidism in children and adolescents. J Chin Med Assoc 2012; 75: 425-34.

13. Caldwell L, Vora A, Oo Y. Role of genetic screening for FHH in a patient with hypercalcemia and hyperparathyroidism. J Endocr Soc 2019; 3: SAT-504.

14. Tosur M, Lopez ME, Paul DL. Primary hyperparathyroidism versus familial hypocalciuric hypercalcemia: a challenging diagnostic evaluation in an adolescent female. Ann Pediatr Endocrinol Metab 2019; 24: 195-8.

15. Lee JY, Shoback SM. Familial hypocalciuric hypercalcemia and related disorders. Best Pract Res Clin Endocrinol Metab 2018; 32: 609-19. 
16. Taki K, Kogai T, Sakumoto J, et al. Familial hypocalciuric hypercalcemia with a de novo mutation of calcium-sensing receptor. Endocrinol Diabetes Metab Case Rep 2015; 2015: 150016.

17. Nesbit MA, Hannan FM, Howles SA, et al. Mutation affecting G-protein subunit a11 in hypercalcemia and hypocalcemia. $\mathrm{N}$ Engl J Med 2013 Jun 27; 368: 2476-86.

18. Vahe C, Benomar K, Espiard S, et al. Diseases associated with calcium sensing receptor. Orphanet J Rare Dis 2017; 12: 19.

19. Stratta P, Merlotti G, Musetti C, et al. Calcium-sensing-related gene mutations in hypercalcaemic hypocalciuric patients as differential diagnosis from primary hyperparathyroidism: detection of two novel inactivating mutations in an Italian population. Nephrol Dial Transplant 2014; 29: 1902-9.

20.Lopez CA, Anton-Martin P, Gil-Fornuer B, et al. Familial hypocalciuric hypercalcemia: new mutation in the CASR Gene converting Valine 697 to Methionine. Eur J Pediatr 2012; 171: 147-50.

21. Szalat A, Shpitzen S, Tsur A, et al. Stepwise CaSR, Ap2S1, and GNA11 sequencing in patients with suspected familial hypocalciuric hypercalcemia. Endocrine 2017; 55: 741-7.

22. Alon US, VanDeVoorde RG. Beneficial effect of cinacalcet in a child with familial hypocalciuric hypercalcemia. Pediatr Nephrol 2010; 25: 1747-50.

23. Marx SJ. Calcimimetic use in familial hpyocalciuric hypercalcemia- a perspective in endocrinology. J Clin Endocrinol Metab 2017; 102: 3933-6. 